\title{
Antioxidant, Pharmacological, Medical Properties and Chemical Content of Rosa L. Extracts
}

\author{
Shyryn Tolekova ${ }^{1}$, Turegeldy Sharmanov ${ }^{2}$, Yury Sinyavskiy ${ }^{3}$, Ramza Berzhanova ${ }^{4}$, \\ Ramazan Mammadov ${ }^{(i, *}$, Ozge Kilincarslan Aksoy ${ }^{(i)}$, Rusif Yusifli 6
}

\author{
${ }^{1}$ Kazakh Academy of Nutrition, Kazakh National University, Almaty, Kazakhstan \\ ${ }^{2}$ Kazakhstan Academy of Nutrition, Almaty, Kazakhstan \\ ${ }^{3}$ Department of Food Biotechnology, Almaty Technical University, Almaty, Kazakhstan \\ ${ }^{4}$ Department of Biotechnology, Al-Farabi Kazakh National University, Almaty, Kazakhstan \\ ${ }^{5}$ Molecular Biology and Genetics, Faculty of Science, Muğla Sıtkı Koçman University, Muğla, Turkey \\ ${ }^{6}$ Department of Biology, Faculty of Art \& Science, Pamukkale University, Denizli, Turkey
}

\begin{abstract}
Currently, increased attention is paid to plant raw materials as a source of biologically active substances. As a consequence of this great scientific interest is dog rose (lat. Rosa), a genus of wild plants of the Rosaceae family (Rosales) and it is widely used as a medicinal, vitamin source and food raw material. The species of Rosa genus have rich vitamin content and different chemical structures. Dog rose has medicinal value as a multivitamin remedy. Many works have been devoted to the study of the dynamics of the accumulation of vitamins depending on the forms and types of dog rose, geographic location, meteorological conditions, soil, fertilizer application and other environmental factors. The most economically valuable part of the dog rose is the pulp of the fruit. Rosa is used in official and traditional medicine. They also have anti-inflammatory, choleretic, diuretic properties and a beneficial effect on carbohydrate metabolism and, they regulate the activity of the gastrointestinal tract, enhance tissue regeneration, the synthesis of hormones. In this review article, antioxidant, pharmacological, medical properties and chemical content of the Rosa genus has been discussed in detail.
\end{abstract}

\section{ARTICLE HISTORY}

Received: September 22, 2019

Revised: April 23, 2020

Accepted: June 18, 2020

\section{KEYWORDS}

Rosa L.,

Antioxidant,

Antibacterial,

Phytochemicals,

Medicine

\section{INTRODUCTION}

Rosa L. is an upright broadleaf shrub, and its height reaches up to 1-2 m [1, 2]. Stems and branches are usually spiked. There are more than 120 species of wild rose in the world and they are widespread in temperate and subtropical zones of the Northern Hemisphere, and occasionally in the mountainous regions of the tropical belt [3, 4]. Some species of wild rose penetrate northward to the Arctic Circle, and southward to Ethiopia, Arabia, Northern India, and the Philippine Islands, and from North America to Mexico. Especially favorable conditions for its growth are in the region from the Mediterranean to the Himalayas and further in East Asia (Figure 1). These plants are resistant to harsh environmental conditions (rocky and sloping terrain, poor soil, lack of water) [5].

CONTACT: Ramazan Mammadov $₫$ rmammad@yahoo.com $\equiv$ Molecular Biology and Genetics, Faculty of Science, Muğla Sitkı Koçman University, Muğla, Turkey 
Pliny the Elder (23-79 AD) was the first person to describe the healing properties of Rosa when they saw and observed that French ethnic groups use for the treatment of dog bites. Because of this usage for treatment of dog bites, they gave "dog rose" name for it [6]. Rosa was also used by a German woman in Europe to make tea that could cure certain diseases. Because of their high content of vitamin C, "dog rose" became a main source of vitamin C in the UK during World War II, the government organized its enormous harvest [7]. Moreover, the great Iranian physician Avicenna (AD 980-1037) mentioned Rosa in his book "The Canon of Medicine" as alighol-kalb (most of the dog) and he indicated that it can treat ulcers, including mouth ulcers and strengthening of the gums [8]. An excellent source of vitamin C, rosehip is an effective medicinal plant for the treatment of gingivitis and swollen or bleeding gums [910], which are the main clinical manifestations of scurvy (vitamin $\mathrm{C}$ deficiency).

The value of Rosa was confirmed after the publishing of stamps with images of 23 species in 19 countries [11]. It should be noted that various parts of this plant have traditionally been used to treat various diseases. Its root, for example, has been used to treat cough Rosa, hemorrhoids, and dysuria. Its leaves are used in the treatment of colds, flu and cough, and its branches are useful in the treatment of urolithiasis. Also, its fruits were used to treat asthma, bronchitis and the common cold. Finally, its seeds have been used to treat osteoarthritis, rheumatism and gout [12].

A study conducted in 2010 on six plant species, including Rosa that was collected from Southern Europe, indicated that had excellent antioxidant properties, so it could be used as an alternative to synthetic antioxidants [13]. Since plants are among the rich sources of antioxidant compounds, the amount of antioxidant compounds in dietary plants, including various types of fruits, berries, vegetables, cereals, nuts and beans, has been investigated. The results showed that between different antioxidants in different food plants more than 1000 times Rosa hips, cherries, blackberries, strawberries, raspberries, sunflower seeds and pomegranates are the plants with the most antioxidants [14].

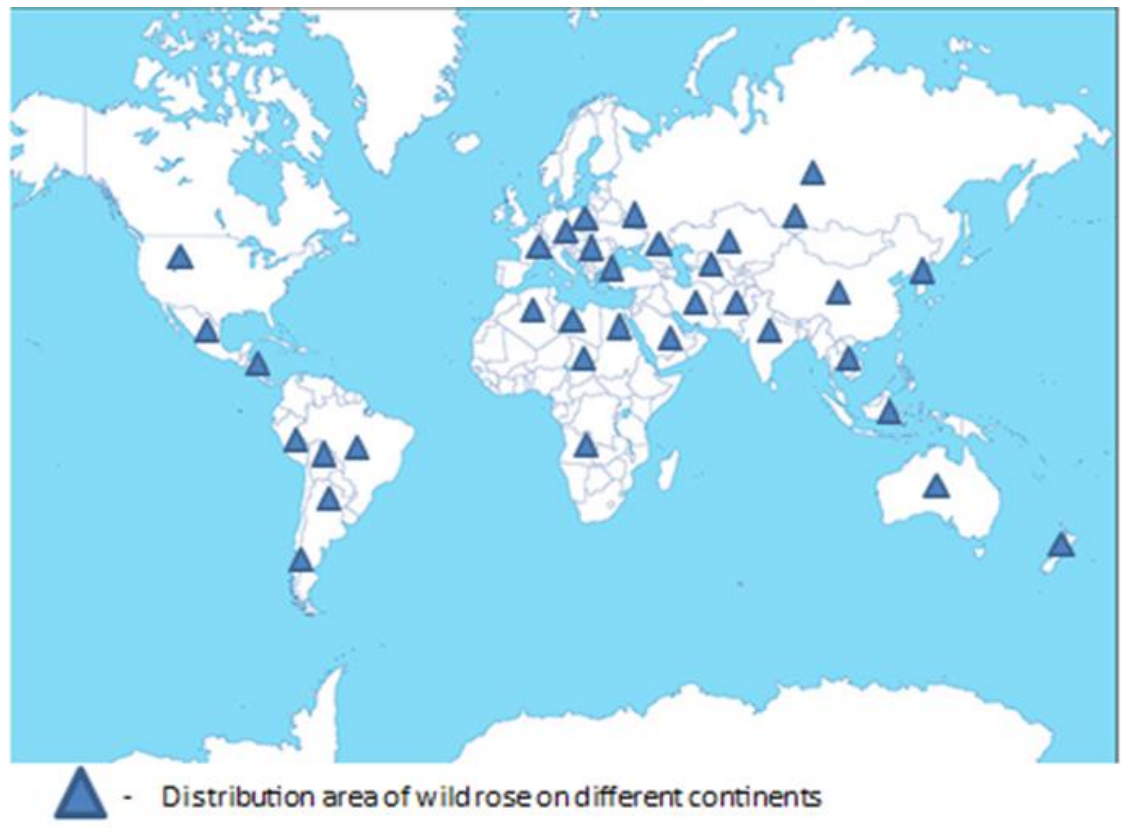

Figure 1. Habitats of all Rosa species around the world. 


\subsection{Plant Material and In Vitro Culture Conditions}

The chemical composition of Rosa is well studied, including modern high-precision methods of analysis. Minerals of the plants are easily digestible form, they have high biological activity involving biochemical processes in the human body [15]. In the study of Rosa fruits by the mass spectrometry method revealed the presence of 16 mineral elements [16]. Shanina and Rubchevskaya [15] studied the mineral composition by the spectral method on a DFS-8 instrument and determined the presence of 28 elements. In the mineral composition of Rosa hips was determined by using the atomic absorption method [17, 18]. Data on the mineral composition of the wild rose fruits and leaves are presented in Table 1. It should be noted that, despite the different collection sites and different methods of analysis of plant raw materials, potassium and calcium are the prevailing mineral elements $[15,16,18]$.

Table 1. Mineral elements of Rosa [40, 44].

\begin{tabular}{|c|c|c|}
\hline \multirow[t]{2}{*}{ Treatment $(\mathrm{mM})$} & \multicolumn{2}{|c|}{ Content } \\
\hline & In Fruits & In Leaves \\
\hline \multicolumn{3}{|c|}{ Macronutrients } \\
\hline Potassium & $7.05-12.17 \mathrm{~g} / \mathrm{kg}[16]$ & $5.80-5.82 \%[15]$ \\
\hline Calcium & $7.63-15.65 \%[15]$ & $6.23-6.25 \%[15]$ \\
\hline Magnesium & $150-180 \mathrm{mg} \%$ [17] & $11.60-11.61 \%[15]$ \\
\hline Sodium & $150-180 \mathrm{mg} \%$ [17] & $4.64 * 4.69 \%[15]$ \\
\hline Phosphorus & $4.28-10.80 \mathrm{~g} / \mathrm{kg}[16]$ & $(1.71-1.711) 10-3 \%[15]$ \\
\hline \multicolumn{3}{|c|}{$\begin{array}{l}\text { Trace elements } \\
\end{array}$} \\
\hline Silicon & $1,20-11,60 \%[15]$ & $1,160-1,28 \%[15]$ \\
\hline \multirow[t]{4}{*}{ Manganese } & $24,91-50,70 \mathrm{mg} / \mathrm{kg}[16]$ & $(65,0-200,0)^{*} 10-3 \%[15]$ \\
\hline & $(122,0-239,0) 10-3 \%[15]$ & \\
\hline & $124-189$ mkg/100 g [17] & \\
\hline & $0,37-0,59 \mathrm{mg} \%[16]$ & \\
\hline \multirow[t]{4}{*}{ Copper } & $3,92-14,41 \mathrm{mg} / \mathrm{kg}[18]$ & $(11,52-25,60) * 10-3 \%[15]$ \\
\hline & $(22,87-47,80) 10-3 \%[15]$ & \\
\hline & $0,1-0,15 \mathrm{mg} / \mathrm{kg}[17]$ & \\
\hline & $0,28-0,35 \mathrm{mg} \%[16]$ & \\
\hline \multirow[t]{4}{*}{ Zinc } & $3,92-14,41 \mathrm{mg} / \mathrm{kg}[18]$ & $(6,50-25,70) * 10-3 \%[15]$ \\
\hline & $(22,87-47,80) 10-3 \%[15]$ & \\
\hline & $0,1-0,15 \mathrm{mg} / \mathrm{kg}[17]$ & \\
\hline & $0,28-0,35 \mathrm{mg} \%[15]$ & \\
\hline \multirow[t]{3}{*}{ Nickel } & $1,01-2,42 \mathrm{mg} / \mathrm{kg}[16]$ & $(0,70-1,80) * 10-3 \%[15]$ \\
\hline & $1,7-3,4 \mathrm{mkg} / 100$ г [17] & \\
\hline & $(4,58-7,17) 10-3 \%[15]$ & \\
\hline \multirow[t]{2}{*}{ Cobalt } & $<0,003 \mathrm{mg} / \mathrm{kg} \%[18]$ & \\
\hline & $0,48 * 10-3 \%[15]$ & \\
\hline Aluminum & $0,13-3,48 \%[15]$ & $1,06-1,75 \%[15]$ \\
\hline
\end{tabular}

\subsection{Plant Material and In Vitro Culture Conditions}

Rosa is considered as a raw material of multivitamin (Table 2). It is rich in a natural source of vitamin $\mathrm{C}$, the content of which exceeds currants 10 times and lemon fruits fifty times [1]. At the same time, the biological role of vitamin $C$ is manifested in the presence of organic acids and P-active compounds, which include anthocyanins, catechins, leucoanthocyanins and flavonols, which differ in chemical composition, but have a similar effect on the human body 
[28]. Flavonoids act as antioxidants and inactivate free radicals in the presence of metals [29]. In the fruits of the plant of the genus Rosa, they are represented in particular by quercetin, hyperoside, astragalin, rutin, kaempferol-3-arabinoside, etc. [30].

Table 2. Vitamins and biological active substances of Rosa hips and leaves [40, 44].

\begin{tabular}{|c|c|c|c|}
\hline Substance & Content & Substance & Content \\
\hline & Rosehips & & Leaves \\
\hline \multirow[t]{5}{*}{ Vitamin $\mathrm{C}$} & $1007.63-1901.47 \mathrm{mg} \%[2,20]$ & \multirow[t]{5}{*}{ Vitamin C } & \multirow[t]{5}{*}{$11,60-218,80 \mathrm{mg} \%[2]$} \\
\hline & $203.09-1082.69 \% \mathrm{mg}$ [25] & & \\
\hline & 498.96-947.69 mg\% [12] & & \\
\hline & $681-840 \%$ UHB * [3] & & \\
\hline & $\begin{array}{l}\text { 2483.65-3577.07 mg\% DM ** } \\
{[13]}\end{array}$ & & \\
\hline Vitamin P & $184.0 \mathrm{mg} / \mathrm{kg}[10]$ & Vitamin P & $0,72-1,30 \mathrm{mg} \%[2]$ \\
\hline Vitamin B1 & $0.73-0.90 \mathrm{mg} \%[2,6]$ & Vitamin B1 & $0,20-1,67 \mathrm{mg} \%[2]$ \\
\hline Vitamin $\mathrm{K}$ & $1.40-2.00 \mathrm{mg} \%[2,6]$ & Vitamin K & $0,15-1,40 \mathrm{mg} \%[2]$ \\
\hline Flavonoids & $\begin{array}{l}\text { 78-102 mg of EGC } * * * / g ~ C B \\
\text { [3] }\end{array}$ & Flavonoids & $\begin{array}{l}0,10-0,45 \mathrm{mg} \mathrm{ER} * * * * / \mathrm{ml} \\
{[14]}\end{array}$ \\
\hline Polyphenolic & $48.8 \mathrm{mg} / \mathrm{kg}[10]$ & Lycopene & $0,03-0,005 \mathrm{mg} / \mathrm{ml}[14]$ \\
\hline Substances & $4.80-5.90 \%[10]$ & $\beta$-carotene & $0,188-0,277 \mathrm{mg} / \mathrm{ml}[14]$ \\
\hline Flavonols & $3.28-4.20 \%[12]$ & Total amount & 5,41-8,63 $\mathrm{mg} \quad$ EGK $/ \mathrm{ml}$ \\
\hline Catechins & $62-76 \mathrm{mg} \%[6]$ & $\begin{array}{l}\text { phenolic } \\
\text { compounds }\end{array}$ & \\
\hline Leucoanthocyanins & $740-857$ mg\% [6] & & \\
\hline Anthocyanins & $231-315 \mathrm{mg} \%[6]$ & & \\
\hline Tannins & $877-1370 \mathrm{mg} \%[6]$ & & \\
\hline \multirow[t]{3}{*}{ Chlorophyll } & $5.71-9.1 \%[20]$ & & \\
\hline & $5.20-7.80 \mathrm{mg} \%$ & & \\
\hline & 7.90-5.27 mg\% SV [17] & & \\
\hline
\end{tabular}

* FS - fresh substance; ** DS - dry substances; *** EGA - the equivalent of gallic acid, ER **** Equivalent routine.

Tocopherols [31] were found in the rosehips, the antioxidant properties of which are based on the ability to form stable little-reactive radicals as a result of the cleavage of a hydrogen atom from a hydroxyl group upon interaction with active radicals [32]. Carotenoids 
are represented mainly by lycopene, lutein and $\beta$-carotene [33, 34]. Their role is to bind singlet oxygen and inhibit the formation of free radicals, which helps to prevent the negative effect of the latter on the body $[33,35]$. The number of carotenoids increases during the growing season, while the number of chlorophylls decreases [36]. Vitamin and mineral compositions of Rosa depends on many environmental factors, but the main ones are ecological and genetic. The ecological factor is the leading one; it is explained by the composition of the water, the nature of the microorganisms and the soil structure, the quality and quantity of the fertilizers applied $[37,38]$. A huge role in this process is played by the soil, which contains mobile forms of mineral substances that are successfully absorbed by the plant and contribute to the normal course of the synthesis of vitamins and other important organic compounds. With an increase in the height of the growth of shrubs above sea level, the content of ascorbic acid, carotene, catechins, leucoanthocyanins, anthocyanins, and flavonols increases, but the content of tannins in fruits decreases [39]. At the same time, in addition to the rosehips, Rosa leaves have a rich chemical composition (Table 2). Rosa leaves occupy the second place in the content of ascorbic acid concerning the vegetative part of the plant [36]. In the leaves of wild rose, the presence of such biologically active substances as carotenoids, chlorophylls, tocopherols and flavonoids has been revealed [35, 40]. Ascorbic acid is found in significant amounts in products of plant origin (Rosa hips, primrose leaves, etc.) and it plays an important role in the vital activity of the organism. Due to the presence of a diene group in the molecule, ascorbic acid has strongly pronounced reducing (antioxidant) properties [41].

As a result of a phytochemical study (Table 3) of Rosa roots growing in the North Caucasus, the presence and content of biologically active compounds were determined: organic acids, water-soluble polysaccharides, pectinaceous substances, ascorbic acid, tannins and easily oxidizable substances, tannin, triterpenic saponins, amino acids. Arginine, glutamic acid, aspartic acid, and lysine predominate in the amino acid composition of Rosa roots. Defined macro-and microelement composition. The results indicate the promise of further research of raw materials and drug production [27].

The advantages of natural origin food and non-toxic antioxidants are obvious when compared with synthetic ones. It is known that non-toxic antioxidants are found in vegetable oils, plant extracts and other plant products [43]. Therefore, along with the study of the chemical composition, the authors widely studied the effect of the vegetative part of Rosa, containing natural antioxidants, on the mechanism of inhibition of oxidative processes [44]. The authors also confirm that the sugar or ascorbic acid content in the extract is responsible for the antioxidant activity of rose hips [45].

\subsection{Medical Meaning of Rosa}

For hundreds of years, Rosa raw materials used in scientific and traditional medicine. Rosa is a pharmacopoeial raw material that is used as a vitamin remedy. The oils prepared from the rosehips have wound-healing and choleretic effects. A promising and important direction in the development of pharmacy is the comprehensive study and rational usage of the whole plant [46].

Ancient medicine defined the nature of Rosa as hot and dry in the II degree. It opens the blockage in the internal organs and cleans. The smell of Rosa strengthens the heart, brain, sense organs, the brain is hot, heals the cold of nerves. It kills worms in the ear and helps with ringing in the ears, and also it is good for toothache. When Rosa is applied to forehead, it can heals a headache [47]. 
Table 3. The content of biologically active compounds in Rosa genus roots [42].

\begin{tabular}{|c|c|c|}
\hline Biologically active compounds & Analysis method & Metrological specifications \\
\hline \multirow{4}{*}{ Free organic acids in terms of on apple acid } & \multirow{4}{*}{ Alkalimetry } & $S=0,0474342$ \\
\hline & & $\mathrm{SX}=0,0212138$ \\
\hline & & $\mathrm{X} \pm \Delta \mathrm{X}=8,06 \pm 0,047$ \\
\hline & & $\varepsilon= \pm 0,58 \%$ \\
\hline \multirow{4}{*}{ Ascorbic Acid } & \multirow{4}{*}{ Titrimetry } & $S=0,0035637$ \\
\hline & & $S X=0,0015938$ \\
\hline & & $\Delta X=0,0035417$ \\
\hline & & $\mathrm{X} \pm \Delta \mathrm{X}=0,262 \pm 0,0035$ \\
\hline \multirow{6}{*}{ Tannin } & \multirow{5}{*}{ HPLC } & $\mathrm{N}=5 \mathrm{f}=4$ \\
\hline & & $S=0,02645$ \\
\hline & & $\mathrm{SX}=0,011832$ \\
\hline & & $\Delta X=0,0262942$ \\
\hline & & $\mathrm{X} \pm \Delta \mathrm{X}=1,46 \pm 0,026$ \\
\hline & & $\varepsilon= \pm 1,80 \%$ \\
\hline \multirow{5}{*}{ Saponins } & \multirow{5}{*}{ Gravimetry } & $S=0,0238747$ \\
\hline & & $S X=0,0106774$ \\
\hline & & $\Delta X=0,0237273$ \\
\hline & & $X \pm \Delta X=4,66 \pm 0,0237$ \\
\hline & & $\varepsilon= \pm 0,51 \%$ \\
\hline \multirow{5}{*}{ Amino Acids in recalculated on alanine. } & \multirow{5}{*}{ Spectrophotometry } & $S=0,015379$ \\
\hline & & $S X=0,006878$ \\
\hline & & $\Delta \mathrm{X}=0,015284$ \\
\hline & & $\mathrm{X} \pm \Delta \mathrm{X}=3,788 \pm 0,015$ \\
\hline & & $\varepsilon= \pm 0,40 \%$ \\
\hline
\end{tabular}

Rosa is very popular in traditional medicine. Its boiled fruits are used as a choleretic and fortifying agent. When Rosa juice is drunk with honey, it can act as a diaphoretic and it can remedy colds, hypertension, liver diseases.The local population of Central Asia prepares preserves of wild rose petals andthey use it as a heart booster and a sedative. The boiled Rosa galls are used for treatment of gastric ulcer, duodenal ulcer, malaria, and pulmonary tuberculosis [48]. Jam of its flowers relaxes, heals the heartbeat. It is useful for tumors of the throat and tonsils. Treatment of wild rose flower petals eliminates the unpleasant smell of sweat in the bath. of the boiled rose hips treat stomach cancer. the boiled galls help to remedy the hemorrhoids, soothes pain and burning. Hippocrates used rosehip for treatment of gallbladder disease. Dioscorides also used it for abdominal pain. Rosa juice was used as a fixative and hemostatic agent $[49,50]$. the boiled branches and leaves of Rosa are used for stomach pain, dysentery and boiled roots of it are drunk as a strong diuretic for urolithiasis. the grinded seeds of Rosa, with alum, are used for treatment of external wounds. The branches of the plant are burned, and a resinous substance is obtained. With this remedy, psoriasis is typically treated [51]. In Russian traditional medicine, Rosa tincture on vodka (1:10) is used in the treatment of diarrhea. Rosa liqueur ( 1 cup of fruit is drawn into the Sun with 1.5 cups of sugar in 3 cups of vodka, for 5 days) is drunk 15-20 grams each, after food as an anticonvulsant, painkiller [52]. In Chinese traditional medicine, the roots of the Rosa are used as an antihelminthic. In Tibetan traditional medicine, Rosa flowers are used for treatment of neurasthenia, atherosclerosis, and tuberculosis. In Mongolian traditional medicine, Rosa is used in the treatment of headaches, 
dizziness, burning skin. In Bulgarian folk medicine, fruits, Rosa flowers are used as a choleretic, sedative [53].

In modern scientific medicine, Rosa has also very widely usage. At First, all of its fruits are used as a source of vitamin C. 5-6 rosehips, fully provide a daily dose of this vitamin. Thanks to vitamin $\mathrm{C}$ and polyphenols, the rosehips of its leaves have a pronounced antioxidant and anti-inflammatory effect [54-57].

Experimental studies have revealed the immunomodulatory properties of Rosa extract $[58,59]$. Rosa has been successfully applied to prevent morbidity among frequently ill children [60]. Its positive effects on diseases of the liver and gallbladder are noted. Rosa preparations normalize the secretion of the digestive tract, have a sedative, hemostatic effect [61].

Rosa is widely used for treatment of type II diabetes [62, 63]. Rosa hips have a hypolipidemic and hypoglycemic effect in diabetes mellitus [64]. Plant extracts inhibit the enzyme $\alpha$ amylase [65]. Prolonged intake of Rosa prevents cognitive impairment in diabetic patients [66].

Experimental studies have shown that rosehip extracts inhibit lipid accumulation in white adipose tissue, increases fatty acid oxidation processes in the liver and skeletal muscle, thereby preventing the development of obesity [67].

Randomized placebo-controlled studies have shown that taking Rosa for 12 weeks reduces the fatty lining of the abdomen, the body mass index in patients prone to obesity, and prevents the development of obesity [68]. Clinical, randomized, controlled studies have shown that the fruits, rosehips and seeds improve the condition of patients with osteoarthritis [69- 75].

Quercetin, isolated from Rosa, inhibited the activity of melanogenesis in melanoma cells [76, 77]. Rosa leaf extracts have an antiproliferative effect on leukemia [78], colon tumors [79]. Thanks to flavonoids and vitamin C, Rosa extracts have an antitumor effect [80]. The marked stimulating effect of Rosa on the secretion of the adrenal gland and thyroid gland. Rosa preparations stimulate the immune system, and therefore, it is advisable to prescribe them in infectious diseases [61].

Hot infusions of Rosa can be presented as a functional food for individuals with a high level of urates, and as a therapeutic agent for hyperoremic patients [81]. Rosa leaf extracts have antidiarrheal properties [82]. Rosa extracts prevent hepatic from tetrachloride methane damage [83].

Fruits harvested from various types of Rosa, belonging to the three sections, are used as medicinal plant raw materials: Cinnamomeae sections (high vitamin types) - May rosehip (brown rosehip) (R. canina (L.), Acicular rosehip (R. acicularis Lindl. ), Daurian rosehip (R. davurica Pall.), Begger's rosehip ( $R$. beggeriana Schrenk), Fedchenko's rosehip (R. fedtschenkoana Regel), Kokand rosehip (R. Kokanica (Regel) Regel ex Juz.); Rugosae sections (high vitamin types ) - wrinkled briar (R. rugosa Thunb.); and Caninae sections (low vitamin types) - canine briar ( $R$. canina L.), briar shchitkon wasp ( $R$. corymbifera Borkh.), dog rose small-flowered ( $R$. micrantha Smith.), dog rose sand-loving ( $R$. psammophila Chrshan.), dog rose felt ( $R$. tomentosa Smith.), dog rose zangezura ( $R$. zangezura P. Jarosch.) [84- 86].

The raw material is a whole, peeled from the sepals and peduncles false fruits of various shapes: from spherical, ovoid or oval to highly elongated spindle-shaped. The length of the fruit is $0.7-3 \mathrm{~cm}$, diameter $-0.6-1.7 \mathrm{~mm}$. At the top of the fruit there is a small round hole (in species of the Cinnamomeae section) or a pentagonal platform (in species of the Canina section). Fruits consist of overgrown, fleshy, when ripe juicy receptacle and numerous fruitnuts enclosed in its cavity. The outer surface of the fruit is shiny, less often matte, more or less wrinkled. Inside, the fruit is covered with long, bristly hairs [87]. Nuts are small, oblong, with weakly expressed edges. The color of fruits is from orange-red to brownish-red, the nuts are 
light yellow, sometimes brownish. The smell is absent. The taste is sour-sweet, slightly astringent [85]. There are differences in the preparation of high and low vitamin species. The types with high vitamin content are harvested in August-September. In the instructions for harvesting indicated that the harvesting of fruits should be completed before frost, since after frost during thawing, the content of ascorbic acid in the raw material is reduced. After harvesting fresh Rosa can be stored no more than 3 days [86]. When fruits of Rosa type with high vitamin content are dired, the various type deyers are used and the fruits exposure at 80$90 \mathrm{C}^{\mathrm{o}}$. It is considered that at this temperature, the fruit dries quickly without significant loss of ascorbic acid [86, 88].

The collection of low vitamin A species of Rosa is carried out throughout the autumn from the moment of their full reddening to frosts. Fruits should not be harvested until they are completely reddened, since the immature raw materials contain insufficient organic acids and carotenoids [86]. To dry low vitamin A species of Rosa, both artificial and natural air drying can be used [86].

\section{CONCLUSION}

The chemical composition of the Rosa is quite rich, so broths, medical extracts and syrups are prepared from its dried fruits. Rosa is rich in many vitamins, minerals and tannins. It also has pectin, organic acids and sugar, which is easily digested. Due to the chemical composition of the rosehips, they contain useful for the body bioflavonoids with antioxidant action. They also help protect the body from aging and detoxify. Rosa is extremely useful, they allow a person to replenish stocks of missing vitamins, trace elements, essential acids and antioxidants. The simplest use of Rosa for the prevention of beriberi is a drink from its dried fruits.

Rosa is an excellent therapeutic and prophylactic agent. It is widely used in medicine, cosmetology and cooking. But when it is used it is worth remembering that everything is good in moderation. It is also necessary to take into account that the use of Rosa has a number of contraindications, therefore, you must first consult with your doctor.

\section{Acknowledgements}

This research was not received any grant or fund support from public or commercial sectors.

\section{Declaration of Conflicting Interests and Ethics}

The authors declare no conflict of interest. This research study complies with research publishing ethics. The scientific and legal responsibility for manuscripts published in IJSM belongs to the author(s).

\section{Orcid}

Ramazan Mammadov (D) https://orcid.org/0000-0003-2218-5336

Ozge Kilincarslan Aksoy (D) https://orcid.org/0000-0003-4944-1029

Rusif Yusifli (D) https://orcid.org/0000-0002-8429-5373

\section{REFERENCES}

[1]. Barros L., Carvalho A.M., Ferreira, I.C.F.R. (2011). Exotic fruits as a source of important phytochemicals: Improving the traditional use of Rosa canina fruits in Portugal. Food Research International, 44 (7), 2233-2236.

[2]. Mukhametova, S.V. (2016). Parameters of fruiting and the biochemical characteristics of rosehip varieties in Mari., Bulletin of the Volga State University of Technology. Ser. Les. Ecology Environmental Management, 2 (30), 94-103. 
[3]. Maksyutina, N.P., Komissarenko, N.F., Prokopenko, A.P. (1985). Herbal remedies. Kiev. Health, pp. 280.

[4]. Shanina, E.V., Rubchevskaya, L.P. (2003). Rosa acicularis is a source of vitamins. Chemistry of Plant Materials, 1, 65-67.

[5]. Yilmaz, S.O., Ercisli, S. (2011). Antibacterial and antioxidant activity of fruits of some rose species from Turkey, Romanian Biotechnological Letters, 16, 6407-6411.

[6]. Heinemann, W. (1966). The Older Pliny. Natural History Vll, books XXIV-XXV1l: London (ISBN: 0-434-99419-7).

[7]. Haas, L. (1995). Rosa canina (dog rose). Journal of neurology, neurosurgery, and psychiatry, 59(5), 470.

[8]. Sharafkandi, A. (2008). The Persian Translation of Qanoun Fi Al-Tibb (Or the Canon of Medicine), Vol. 2. Soroush Press, Tehran, Iran.

[9]. Pimentel, L. (2003). Scurvy: historical review and current diagnostic approach. The American journal of emergency medicine, 21(4), 328-332.

[10]. Yee, Y.C., Ying, T.P., Wei, N.S. (2017).The Oldest Nutritional Deficiency Disease: A Case Report Of Scurvy. Malaysian Journal of Paediatrics and Child Health, 22, 41-45.

[11]. Erkin, Ö., Winther, K., Campbell-Tofte, J., Hansen, A.S. (2015). Herbal Medicine in Stamps: History of Rosa Canina through Philately. Bioactive ingredients of rose hips (Rosa canina L.) with special reference to antioxidative and anti-inflammatory properties: in vitro studies. Botanics: Targets Therapy, 5, 1-13.

[12]. Matasova, S.A., Ryzhova, G.L., Dychko, K.A. (1997). Chimiceskiy sostav suchovo vodnogo ekstrakta iz shrota shipovnika. Chemistry Rast. Raw materials, 2, 28-31.

[13]. Egea, I., Sánchez-Bel, P., Romojaro, F., Pretel, M.T. (2010). Six edible wild fruits as potential antioxidant additives or nutritional supplements. Plant Foods Hum Nutr., 65(2), 121-129.

[14]. Halvorsen, B.L, Holte, K, Myhrstad, M.C, Barikmo, I, Hvattum, E, Remberg, S.F. (2002). A systematic screening of total antioxidants in dietary plants. The Journal of Nutrition. 132(3), 461-471.

[15]. Shanina E.V., Rubchevskaya L.P. (2005). Mineralnıy sostav biomassi Rosa acicularis Lindl. Izvestiya Vuzov Pishevaya Technologiya, 2-3, 47-49.

[16]. Starodub, O.A. (2007). To the question of the mineral composition of rosehips (Rosa L.) growing in the Krasnoyarsk Territory. New advances in chemistry and chemical technology of plant materials: materials of the III All-Russian Conference. Altai State. un-t - Barnaul, Prince., 2, 181-182.

[17]. Petrova, S.N., Ivkova A.V. (2014). Chimiceskiy sostav i antioksidantnie svoystvo vidov roda Rosa L. (Obzor). Chimiya Rastitelnogo Sirya, 2, 13-19.

[18]. Kotenko, M.E., Guseinova, B.M. (2011). Influence of edaphic factors of the Terek-Sulak lowland and the mountainous Khunzakhsky district of Dagestan on the nutrient composition of Rosa canina briar. Naucniy jurnal KubGAU, 66(2),78-85.

[19]. Checheta, O.V., Safonova, E.F., Slivkin, A..I.., Snopov, S.V. (2011). Determination of flavonoids in rose hips (Rosa Sp.). Bulletin of Voronezh State University. 1, 62-64.

[20]. Roman, I., Andreea Stănilă, A., Stănilă, S. (2013). Bioactive compounds and antioxidant activity of Rosa canina L. biotypes from spontaneous flora of Transylvania. Chem Cent J., 7(73), 1-10.

[21]. Lovkova, M.Ya., Rabinovich, A.M. et al. (1990). Pochemu rasteniya lechat (in Russian) Hardcover. Nauka, Moscova, pp. 256.

[22]. Taneva, I., Dobreva, K., Petkova, A.N., Panchev, I., Denenev, P. (2013). Isolation and characterization of pectic substances from Rosa canina L. Food Science and Technology, 24(3), 38-40 
[23]. Dubtsova, G.N., Negmatulloeva, R.N., Bessonov, V.V., Baikov, V.G., Shevyakova, L.V., Makhova, N.N., Perederaev, OI, Bogachuk , M.N., Baygarin, E.K. (2012). The composition and content of biologically active substances in the hips. Nutrition Issues, 81(6), 84-88.

[24]. Larsen, E., Kharazmi, A., Christensen, L.P., Christensen, S.B. (2003). An antiinflammatory galactolipid from rose hip (Rosa canina) that inhibits chemotaxis of human peripheral blood neutrophils in vitro. J Nat Prod, 66(7), 994-995.

[25]. Sorokopud, F. İvanov, P.P. (2002). İssledovaniye fiziko-chimiceskix svoystv vodnich i vodno-spirtovıch ekstraktov irgi i shipovnika. Chimiya Rastitelnogo Sirya, 2, 111-116.

[26]. Rubtsova, E.L., Koval, I.V., Djurenko, N.I., Palamarchuk, A.P. (2017). Component composition of volatile organic substances of rosehip petals. Plant Varieties Studying and Protection, 13(3), 285-293.

[27]. Ozcan, M. (2002). Nutrient composition of rose (Rosa canina L.) seed and oils. J. Med. Food, 5(3), 137-140.

[28]. Adamczak, A, Buchwald, W., Zielinski, J., Mielcarek, S. (2010). The effect of air and freeze drying on the content of flavonoids, $\beta$-carotene and organic acids in European dog rose hips (Rosa L sect. caninae DC. em. Christ.). Herba Prolonica, 56(1), 7-17.

[29]. Li, Y., Zhang, J-J., Xu, D-P. (2016). Bioactivities and Health Benefits of Wild Fruits (Review) . International Journal of Molecular Sciences, 17(1258), 1-27.

[30]. Checheta, OV, Safonova, EF, Slivkin, A.I., Safonova I.I., Snopov S.V. (2010). The study of the flavonoid composition of the fruit of the plant of the genus Rosa. Bulletin of VSU. Series: Medicine. Pharmacy, 22(12-2), 119-122.

[31] Pisarev D.I., Novikov O.O., Novikova M.Yu., Zhilyakova E.T. 2010. Izuchenie flavonoidnogo sostava shishkoyagod mozhzhevel'nika dlinnokhvoynogo [The study of the flavonoid composition fruit juniper oblonga]. Byulleten' eksperimental'noy biologii $i$ meditsiny, 150 (12), 657-660.

[32]. Smirnova, V.A., Klimochkin, Yu.N. (2008). Vitamins and coenzymes: study guide. Izd. Gos. Tech. University Samara, Samar, pp. 91.

[33]. İlyasoğlu, H. (2014). Characterization of Rosehip (Rosa canina L.) Seed and Seed Oil. International Journal of Food Proporties, 17(7). 1591-1598.

[34]. Encyclopedia of Rose Science, Three-Volume Set / Ed. by T. Debener, S. Gudin. Ed.-inChief A. Roberts. Academic Press, 2003.pp. 1200. ISBN 978-0-12-227620-0.

[35]. Ghazghazi, H., Miguel, M.G., Hasnaoui, B., Sebei, H., Ksontini, M., Figueiredo, A.C., Pedro, L.G., Barroso, J.G. (2010). Phenols, essential oils and carotenoids of Rosa canina from Tunisia and their antioxidant activities. African J. Biotechnology. 9(18), 2709-2716..

[36]. Shanina E.V., Rubchevskaya L.P., Rechkina E.A. (2005). The chemical composition of the fruit Rosa acicularis Lindl. New advances in chemistry and chemical technology of plant materials: mater. II Vserosiyskiy conference Barnaul, 106-108.

[37]. Starodub, O.A. (2009). Ekologo-biochimiceskiye osobennosti shipovnikov, proizrastayushisg v raznix prirodno-klimaticeskish usloviyach Krasnoyarskogo kraya. PhD Thesis, Krasnoyarsk State Tradeeconomic Institute, Krasnoyarsk, 06 March 2009.

[38]. Timofeeva, V.N., Cherepanova, A.V., Basharimova, E.S. (2008). Mineral composition and safety indicators of rose hips. Chranenie i Pererabotka Selskochozyaystvo., 6. 63-65.

[39]. Kotenko, M.E., Guseinova, B.M., Daudova, T.I. (2011). Vliyanie lugovo lesnich pocv Terskogo Sudakskoy nizmennosti i gornogo Dagestana na biochimiceskiy sostav shipovnika. Vestnik DGRU, Techniceskiye Nauki, 15, 177-182.

[40]. Ivanova, A.V., Petrova, S.N. (2012). Kacestvennıy analiz geksanovich ekstraktov listev shipovnika (Korotkaya soobsheniya). Izvestiya Vuzov, Prikladnaya Chimiya I Biotechnologiya, 2, 158-159. 
[41]. USSR State Pharmacopoeia: Vol. 1. (1987). General methods of analysis. USSR Ministry of Health. $11^{\text {th }}$ ed., Ext. M.: Medicine, pp. 336.

[42]. Vdovenko-Martynova, N.N., Kobylchenko, N.V., Blinova, T.I. (2011). The content of biologically active compounds in the roots of wild rose (Rosa canina L.) Flora of the North Caucasus. Medical Journal of the North Caucasus, 2, 51-52.

[43]. Vardanyan, R.L., Vardanyan, L.R., Atabekyan, L.V. (2007). Extracts of seeds of medicinal plants as inhibitors of the oxidation of organic substances. New advances in chemistry and chemical technology of plant materials: mater. III Vseros. conf. Barnaul, Prince. 2, 367-371.

[44]. Ivkova A.V., Petrova S.N. (2012). Sovremennye problemy himicheskoj nauki i obrazovanija: materialy Vserossijskoj konferencii s mezhdunarodnym uchastiem, posvjashhjonnoj 75-letiju so dnja rozhdenija V.V. Kormacheva. [Modern problems of chemical science and education: Proceedings of the All-Russian conference with international participation, dedicated to the $75^{\text {th }}$ anniversary of VV Kormacheva.]. Cheboksary, part II. pp. 136-137. (in Russian).

[45]. Duda-Chodak, A., Tarko T., Rus M. (2009). Antioxidant activity of selected herbal plants. Herba Polonica, 55(4), 65-77.

[46]. Sokolov, S.R., Svyazeva, O.A., Kubli, V.A. (1980). Areali Derevev i Kustarniki SSSR. Greçişnıye-Rozatsvetnıye, Akademiya Nauk, Botaniceskiy Institut, Elm publishing, Leningrad, 2, $144 \mathrm{p}$.

[47]. Alekperli, F. (2001). Tisyaca odin secret Vostoka. Tural Publishing, Baku, Azerbaijan, 2001, 494 p.

[48]. Karomatov, I.D. (2012). Prostıe lekarstvennie sredstva. Durdana Publishing, Buhara, Uzbekistan. 2012, pp.316-328. ISBN: 978-9943-4005-4-2.

[49]. Sokolov, S. Ya., Svyazev, O. A., Kubli, V. A. (1977). Areas of trees and shrubs of the USSR. Taxaceae- Aristolochiacae. Leningrad, Science, 1, 164.

[50]. Karimov, U.I. (1980). O medisinskim nasledii İbn Sina, Abu Ali Ibn Sina. K 1000 letiyu so dnya rojdeniya Tashkent Fan., pp. 129-149.

[51]. Oproshanska, T.V., Khvorost, O.P., Ocheredko, L.V. (2017). Determination of the quantitative content of the amount of organic acids and ascorbic acid in different batches of Rosa majalis and Rosa canina raw material. News of Pharmacy, 1(89), 10-13.

[52]. Arceusz, A., Radecka, I., Wesolowski, M. (2010). Identification of diversity in elements content in medicinal plants belonging to different plant families. Food Chemistry, 120(1), $52-58$.

[53]. Jordanov D., Nikolov P., Boychinov A. (1972). Phytotherapy. Treatment with officinal herbs. Sofia, pp. 347.

[54]. Daels-Rakotoarison, D.A., Gressier, B., Trotin, F., Brunet, C., Luyckx, M., Dine, T., Bailleul, F., Cazin, M., Cazin, J.C. (2002). Effects of Rosa canina fruit extract on neutrophil respiratory burst. Phytother Res., 16(2), 157-161.

[55]. Deliorman, O. D., Hartevioğlu, A., Küpeli, E., Yesilada, E. (2007). In vivo antiinflammatory and anti-nociceptive activity of the crude extract and fractions from Rosa canina L. fruits. J. Ethnopharmacol, 112(2), 394-400.

[56]. Lattanzio, F., Greco, E., Carrettam D., Cervellati, R., Govoni, P., Speroni, E. (2011). In vivo anti-inflammatory effect of Rosa canina L. extract. J. Ethnopharmacol., 137(1), 880885.

[57]. Wenzig, E.M., Widowitz, U., Kunert, O., Chrubasik, S., Bucar, F., Knauder, E., Bauer, R. (2008). Phytochemical composition and in vitro pharmacological activity of two rose hip (Rosa canina L.) preparations. Phytomedicine, 15(10), 826-835.

[58]. Sadigh-Eteghad, S., Tayefi-Nasrabadi, H., Aghdam, Z., Zarredar, H., Shanehbandi, D., Khayyat, L., Seyyed-Piran, S.H. (2011). Rosa canina L. Fruit Hydro-Alcoholic Extract 
Effects on Some Immunological and Biochemical Parameters in Rats. Bioimpacts, 1(4), 219-224.

[59]. Sanina, I.L. (2012). Travnik polniy spravocnik lekarstvennich rasteniy. Argument Publishing, pp. 463-560.

[60]. Gromova, OA, Galitskaya, S.A., Limanova, OA, Kutuzova, I.A. (2008). Possibilities of micronutrient and phytocorrection in increasing resistance to catarrhal diseases in children. Vopr. Sovr. Pediatrics, 7(6), 156-160.

[61]. Nuraliev, Y. (1988). Medicinal plants. Dushanbe, Print Maorif, Dushanbe, pp. 285 p.

[62]. Fattahi, A., Niyazi, F., Shahbazi, B., Farzaei, M.H., Bahrami, G. (2017). Antidiabetic Mechanisms of Rosa canina Fruits. An In Vitro Evaluation. J. Evid. Based Complementary Altern. Med., 22(1), 127-133.

[63]. Taghizadeh, M., Rashidi, A.A., Taherian, A.A., Vakili, Z., Mehran, M. (2017). The Protective Effect of Hydroalcoholic Extract of Rosa canina (Dog Rose) Fruit on Liver Function and Structure in Streptozotocin-Induced Diabetes in Rats. J. Diet. Suppl., 2, 112.

[64]. Taghizadeh, M., Rashidi, A.A., Taherian, A.A., Vakili, Z., Sajad Sajadian, M., Ghardashi, M. (2016). Antidiabetic and Antihyperlipidemic Effects of Ethanol Extract of Rosa canina L. fruit on Diabetic Rats: An Experimental Study with Histopathological Evaluations. J. Evid. Based Complementary Altern. Med., 21(4), 25-30.

[65]. Demir F, Özcan M. (2001). Chemical and technological properties of rose (Rosa canina L.), fruits grown wild in Turkey. J Food Ing., 7, 333-336.

[66]. Farajpour, R., Sadigh-Eteghad, S., Ahmadian, N., Farzipour, M., Mahmoudi, J., Majdi, A. (2017). Chronic Administration of Rosa canina HydroAlcoholic Extract Attenuates Depressive-Like Behavior and Recognition Memory Impairment in Diabetic Mice: A Possible Role of Oxidative Stress. Med. Princ. Pract, 26(3), 245-250.

[67]. Nagatomo A., Nishida N., Matsuura Y., Shibata N. (2013). Rosehip Extract Inhibits Lipid Accumulation in White Adipose Tissue by Suppressing the Expression of Peroxisome Proliferator-activated Receptor Gamma. Prev. Nutr. Food Scis., 18(2), 85-91.

[68]. Nagatomo, A., Nishida, N., Fukuhara, I., Noro, A., Kozai, Y., Sato, H., Matsuura, Y. (2015). Daily intake of rosehip extract decreases abdominal visceral fat in preobese subjects: a randomized, double-blind, placebocontrolled clinical trial. Diabetes Metab. Syndr. Obes., 6(8), 147-156.

[69]. Rossnagel, K., Willich, S.N. (2001). Value of complementary medicine exemplified by rose-hips. Gesund-Heitswesen, 63(6), 412-416.

[70]. Rein, E., Kharazmi, A., Winther, K. (2004). A herbal remedy, Hyben Vital (stand. powder of a subspecies of Rosa canina fruits), reduces pain and improves general wellbeing in patients with osteoarthritis-a double-blind, placebo-controlled, randomised trial. Phytomedicine, 11(5), 383-391.

[71]. Winther, K., Apel, K., Thamsborg, G. (2005). A powder made from seeds and shells of a rosehip sub-species (Rosa canina) reduces symptoms of knee and hip osteoarthritis: a randomized, double-blind, placebocontrolled clinical trial. Scand. J. Rheumatol., 34(4), 302-308.

[72]. Chrubasik, C., Duke, R.K., Chrubasik, S. (2006). The evidence for clinical efficacy of rose hip and seed: a systematic review. Phytother. Res., 20(1), 1-3.

[73]. Rossnagel, K., Roll, S., Willich, S.N. (2007). The clinical effectiveness of rosehip powder in patients with osteoarthritis. A systematic review. MMW Fortschr. Med., 149(27-28 Suppl), 51-56.

[74]. Chrubasik, C., Wiesner, L., Black, A., Müller-Ladner, U., Chrubasik, S. (2008). A oneyear survey on the use of a powder from Rosa canina lito in acute exacerbations of chronic pain. Phytother. Res., 22(9), 1141-1148. 
[75]. Cheng, B.C., Fu, X.Q., Guo, H., Li, T., Wu, Z.Z., Chan, K., Yu, Z.L. (2016). The genus Rosa and arthritis: overview on pharmacological perspectives. Pharmacological Research, 114, 219-234.

[76]. Fujii, T., Ikeda, K., Saito, M. (2011). Inhibitory effect of rose hip (Rosa canina L.) on melanogenesis in mouse melanoma cells and on pigmentation in brown guinea pigs. Biosci. Biotechnol. Bio-chem., 75(3), 489-495.

[77]. Fujii, T., Saito, M. (2009). Inhibitory effect of quercetin isolated from rose hip (Rosa canina L.) against melanogenesis by mouse melanoma cells. Biosci. Biotechnol. Biochem, 73(9), 1989-1993.

[78]. Zhamanbayeva, G.T., Aralbayeva, A.N., Murzakhmetova, M.K., Tuleukhanov, S.T., Danilenko, M. (2016). Cooperative antiproliferative and differentiation-enhancing activity of medicinal plant extracts in acute myeloid leukemia cells. Biomed. Pharmacother., 82, 80-89.

[79]. Jiménez, S., Gascón, S., Luquin, A., Laguna, M., Ancin-Azpilicueta, C., Rodríguez-Yoldi, M.J. (2016). Rosa canina Extracts Have Antiproliferative and Antioxidant Effects on Caco-2 Human Colon Cancer. PLoS One., 11(7), e0159136.

[80]. Tumbas, V.T., Canadanović-Brunet, J.M., Cetojević-Simin, D.D., Cetković, G.S., Ethilas, S.M., Gille L. (2017). Effect of rosehip (Rosa canina L.) phytochemicals on stable free radicals and human cancer cells. J. Sci. Food. Agric., 92(6), 1273-1281.

[81]. Kikuchi, H., Kogure, S., Arai, R., Saino, K., Ohkubo, A., Tsuda, T., Sunaga, K. (2017). Rosehip inhibits xanthine oxidase activity and reduces serum urate levels in a mouse model of hyperuricemia. Biomed. Rep., 6(5), 539-544.

[82]. Mandade, R.J, A., Harsulkar, A., Wakade, R. (2011). Role of the Rosa canina L. leaf extract as an antidiarrheal drug in rodents. Indian. J. Pharmacol., 43(3), 316-319.

[83]. Sadeghi, H., Hosseinzadeh, S., Akbartabar Touri, M., Ghavamzadeh, M., Jafari Barmak, M., Sayahi, M., Sadeghi, H. (2016). Hepatoprotective effect of Rosa canina fruit extract against carbon tetrachloride induced hepatotoxicity in rat. Avicenna J. Phytomed, 6(2), 181-188.

[84]. Hammerman, A. F. (1984). Medicinal plants (Plants-healers) 3rd ed., Revised. and add. M. Higher. 1984, Medicine, Moscova, 400 p.

[85]. Gosudarstvennaya Farmokopia SSSR. (1990). 11. Vipusk, (Vol. 1-2), MinZdrav. Moscova, SSSR, pp. 137-149.

[86]. Nasri, H., Rafieian-Kopaei, M. (2014). Medicinal plants and antioxidants: why they are not always beneficial? Iran J Public Health, 43(2), 255-257.

[87]. Shevchenko, S.M., Sorokopudov, V.N., Navalneva, I.A. (2011). Dynamics of ascorbic acid in the fruits of plants of the genus Cerasus tomentosa (Thunb.). Chemistry of Plant Raw Materials, 2, 185-186.

[88]. Sabaraykina, S.M., Sorokopudov, V.N., Korobkova, T.S., Sorokopudova, O.A. (2011). Dynamics of ascorbic acid in the fruits of woody plants in Yakutia. Modern problems of science and education, 6, 18-22. 